\title{
THE PECULIARITIES OF THE UKRAINIAN-POLISH LINGUISTIC AND CULTURAL FRONTIER
}

\author{
Nataliia SOVTYS \\ Rivne State University of the Humanities \\ E-mail: NataliaSowtys@gmail.com
}

\begin{abstract}
Prolonged coexistence within a single state, i.e. the Commonwealth of Poland, laid the foundations for the emergence of common cultural and linguistic features along the Ukrainian-Polish borderlands. The article substantiates the peculiarities of the choice of terminology in defining the concepts of "border studies".

Due to the Ukrainian-Polish language contacts, a southern Polish peripheral dialect arose, which was spread over a large territory of the Polish-Lithuanian Commonwealth, and formed the literary Polish language with the ethnic Polish dialects, since the effects of borrowing are recorded in the phonetic and morphological language, as well as stimulating of the internal tendencies of language development.

During the period of increased polonization, we observe the spread of Ukrainian lexical elements in Polish poetry from the middle of the 16th century, while in the 17th century we can see not only the integration of Ukrainianisms into Polish poetry, but even the Ukrainian language in Polish literature can be singled out. Despite the privileged position and dominance of the Polish culture, a unique situation emerged in the context of Ukrainian-Polish contacts along the borderlands when the subordinated Ukrainian folk culture became an ideological and thematically dominant aspect of Polish fiction, painting and music. Of particular interest is the creativity of Polish poets of the "Ukrainian School", for whom the traditions of the Ukrainian people were native, so these authors created their national literature from local language material and played a significant role in the spread of Ukrainian elements in Polish literary language.
\end{abstract}

KEYWORDS: frontier, Kresy, linguistic culture, bilingualism, dialogue of languages and cultures

The frontier is viewed as the place of collision and confrontation of political interests or as the dialogue of languages and cultures. This issue has repeatedly caused a discussion between the representatives of various branches of scientific research. Recent events in the East of Ukraine are also a vivid testimony to the bitter reckoning for the non-disclosure, unwillingness, and inability to identify and resolve issues that arise on the borderlands. The situation in the West of Ukraine is relatively stable politically; however, internal conflicts or external "help" can also provoke ethnic disputes. For example, there are heated discussions concerning the Law on Education and the reactions of the neighboring countries. Thus, the diverse studies of the borderline phenomenon are especially relevant not only to history and to our current Ukrainian realities but also to the future.

The geographical location of Ukraine between the West and the East has led to the pluralism of traditions and customs as well as the representation of the diversity of thoughts and languages. The country appears as an ethnic and cultural mosaic with the distinct features of intellectual and cultural openness. Ukrainian culture, being present in the special forms of ethnic self-identification among different cultural traditions, allows to state dialogue as its characteristic feature. Moreover, Ukrainian culture continues to be an important contact point in a complex chain of dramatic, historical, and political conflicts between European and non-European factors of world history.

The purpose of the article is to investigate the interaction between Ukrainian and Polish linguistic cultures on the frontier lands. It also analyzes the emergence of the peripheral southern Polish dialect and considers the facts of Ukrainian culture popularization by Polish scientists, writers, and artists who have had close connections to Ukraine or who come from ethnic Ukrainian territories.

Ukrainian-Polish borderland studies became active in the 1990s and were predominantly interdisciplinary. However, the issue of outlining the conceptual and terminological metalanguage of "border studies" remains controversial in Ukrainian and Polish studies. Scholarly literature uses the terms "kresy," "frontier," "borderland," "boundary," and "border" (Кирчів, 2009, p. 594 - 595). Until the twenty-first century, Polish historical and literary works used the concept of "kresy" largely in its geographical sense, which emphasizes the belonging of Ukrainian territories to the Polish state. Those works also used the concept in its historical and axiological sense. In addition, there was the "literature of Kresy," which included the literary phenomena that appeared on the territory of the eastern and southeastern borderlands of the Jagiellonian Commonwealth of Poland. Wincenty Pol coined the term "kresy" in his poem Mohort, in which he praised the chivalry of the borderlands protectors. 
Ktoby to myślał, ktoby się spodziewał,

Że gdzieś za światem w bodziakach Czehryńskich,

Że gdzieś na kresach niegdyś Ukraińskich

Taki świat dzielny i uroczy bywał?

(Who would have thought, who would have hoped

That somewhere across the world in the grasses of Chyhyryn,

That somewhere on kresy, once Ukrainian,

Such a mighty and magical world would come to be? $)^{1}$

The term "kresy" is also used in the history of the Polish language and refers to the territory where the Polish language spread and functioned and where it did not have an ethnic basis. That is, where it used foreign Ukrainian and Belarusian-Lithuanian linguistic basis to build on. From the dialectal point of view, eastern Kresy is a territory located to the east of the Polish-Ukrainian ethniclanguage border (Kurzowa, 1993, p. 4). It is important to note that Polish linguistics often interpreted Ukrainian words not as direct borrowings from the Ukrainian language but as Kresy elements. Euphemistically, there was a constant emphasis on the dependence of Ukraine as a state and on the part of its territory belonging to Poland. Under such conditions, it is justified to use such terms as borderland, frontier, boundary, and border. According to O. Sukhomlynov, the term "frontier" is the same as the Polish term "kresy". Despite its connection to "borders," "frontier" includes extraterritoriality and accessibility and denotes the space where intercultural communication, interlingual interference, and literary diffusion take place; this concept is more comprehensive, objectively predetermined, and conceptually grounded (Сухомлинов, 2008, p. 25). Fictional literature, which is biographically or thematically associated with the "frontier", most often reproduces the existing social and cultural model of the region. It has the signs of polyphony and dialogism as well as some exoticism of "the other".

Among Ukrainian scholars, M. Hrushevskyi was the first to use the term "frontier" to denote the lands of Chervona Rus (Грушевський, 1991, p. 31). In modern studies, scholars move away from the spatial perception of the issue and apply a more universal cultural approach (Сухомлинов, 2008, p. 36). The concept of "frontier" is increasingly considered in the context of the intersection, comparison and interaction of cultures, languages, religions, memories, ideological values, identity, etc (Sukhomlynov, 2007-8, p. $183-185$ ). There is the process of adaptation to the atmosphere of continuous collisions of cultures, which sometimes results in an intercultural dialogue. The frontier issue is discussed in the works of Ukrainian and foreign scholars: B. Hadachek, K. Handke, Y. Kolbushevskyi, R. Radyshevskyi, Y. Reshynsky, O. Sukhomlynov, S. Uliasz, E. Chapliievych, and others.

The existence of the first Commonwealth of Poland, namely the period from the end of the 16th to the beginning of the 18th century, laid the foundation for the emergence of common cultural features on the Ukrainian-Polish borderlands. In the 16th century, the Polish state (apart from the annexation of ethnic Ukrainian territories) united several peoples against the threat of Moscow on the one hand and Germany on the other. Thus, Poland assimilated the cultures of these peoples, namely Ukrainians, Belarusians, and Lithuanians, making their traditions the source of its power and vitality.

According to S. Uliasz (1994, p. 51 - 53), the community that was formed on the borderlands, in terms of cultural significance, had a number of universal values, among which there were nine major ones. The first one was polymorphism, that is, the heterogeneity of a single Slavic historical community. The world of the European East was characterized by bilingualism (in the physical and cultural sense) and the potential presence of people with a dual cultural identity, that is, those who freely existed within two or three cultures. The second was cultural federalism, that is, the dialogue of cultures and openness to influences. The result of it is the feeling of responsibility and tolerance towards others. The third was the value of individual and national identity. On the borderlands, with a weakened connection with the center, there was a constant comparison with other ethnic groups, that is between "we" and "others". The fourth value was the ambivalence of the eastern borderland, which is the marginal area but also the zone of potential penetration, which manifests itself in the perception

\footnotetext{
${ }^{1}$ Pol W., (1903) Mohort. Warszawa: Nakładem księgarni Bukowieckiego, 132 s. (S.8).
} 
of the frontiers as constantly threatened territories. The fifth was the value of "little" or "private" homeland. Polissia, Volyn, Hutsulshchyna, Ukraine and Halychyna were such homelands for many writers of Polish origin, including A. Malchevskyi, S. Hoshchynskyi, Y. B. Zaleskyi, Z. Fish, M. Hrabovskyi, Y. Slovatskyi, T. Zaborovskyi, L. E. Venhlynskyi, and many others. Apart from the geographical aspect, "little homeland" acquired personal, sentimental, and even intimate features, which contributed to the making of an artist. There were two obvious tendencies on the borderlands. Because of the common history, there were similarities in traditions and cultures, but each community clearly was striving to preserve their own customs and cultures. Possibly, there were several "private" homelands on those territories, but there was a certain relativity between them and the "ideological" motherland. The sixth value was the figurative embodiment of the aforementioned values, which included home, family, interpersonal relationships as well as nature and landscapes that were the background of history, a form of cultural memory. Often, rivers, barrows, ravines, steppe, or family home served as motifs that functioned as a cultural code and the source of information on frontier history, "little homeland". The seventh value was the concentration of art as a form of search for one's origins. Kresy became not only a place of memory and historical space, but also the center of literary memory and artistic space, where various concepts of expression of the truth about man, nature, and the world were manifested. The eighth value was the culture forming character of the consciousness of the destruction of Polish existence on the frontier lands. The creative idea of the frontier artists developed alongside the constant feeling of the "end," which contributed to the creative liberation and increase of the aesthetic level. The last, ninth value concerned European features of the frontier, which were an integral part of the consciousness of its population. It manifested independently of another vision of the frontier as the place of clashes between nations, cultures, and religions. It is necessary to remember the historical facts that have contributed to the strengthening of the abovementioned features, namely, civilization, cultural, and religious experiments, attempts to connect the East and the West, in particular, church unions.

Certain statements need more attention. Many nations inhabited the frontier, and it became the reason for the existence of multi-language environment, the diversity of cultures and religions, which were transformed into a special cultural phenomenon. Such coexistence with the "other" neighbor on the same territory elevated conflicts that arose because of not only cultural or religious differences but also social ones. This frontier situation maintained its symmetry until political, cultural, or ethnic circumstances changed. At the time of relative social stability, the antinomy "ours - foreign" lost its pronounced opposition, and "foreign" became "the other". When there was an external threat (Islamic or Russian), "the other" could become "ours" and vice versa. Under such circumstances, certain convergence of cultures appeared, which, in turn, resulted in the emergence of local identities where "all ours" were "local". These processes were reflected in many works of frontier writers, such as L. Venhlinskyi's "Military Synbols", Y. Zimorowic's "Sielanki nowe ruskie”, A. Mickiewicz's Pan Tadeusz, W. Pol's Mohort, H. Senkevych's trilogy, J. Iwaszkiewicz's The Moon Rises, etc.

The literary works that emerged among the clashes of various truths (social, geopolitical, national) became the form of search for a dialogue between frontier communities. One of the texts described different cultures that speak with different "voices" but strive to establish a dialogue. For instance, J. Iwaszkiewicz's The Moon Rises managed to demonstrate the kinship between Poles and Russians who had belonged to the so-called upper class since the profound political division did not allow to establish a dialogue. S. Vincenz's "Na Wysokiej Połoninie" captured multiculturalism and tradition diversity. His work describes Hutsuls, Jews, Armenians, and Poles talking "universal" Polish language, which was styled in line with the peculiarities of dialects and individual features of certain characters.

Because of socio-political conditions, a particular type of bilingualism emerged on the borderlands. This bilingualism presupposed the use of Polish in the political sphere, literature, and public speaking while Ukrainian was for domestic family life. Polish became the official frontier and literary language and quickly spread to all the spheres. J. Rieger distinguishes peripheral southern Polish cultural (literary) and conversational dialect. Rural and urban dialects have special places (Rieger, 1993, p. 548 - 550).

Thus, the emergence of peripheral Polish dialect on autochthonous Ukrainian territories is a specific frontier feature. The Polish linguist K. Nitsch was one of the first to focus on the influence of peripheral dialect on the development of the Polish language, which especially increased in the second 
half of the 18th century. Nitsch viewed this dialect as a regional peculiarity of Polish and the frontier, as a dialect area of Poland at the time (1954, p. $216-217)$.

The type of the Polish language that emerged on the frontier was formed from the Polish literary language and had the features of "cultural" dialects, which were literary language in the Polish linguistic tradition. However, it differed from ethnic "cultural" dialects since it did not have the support in autochthonous Polish dialects. Z. Kurzowa (1983) conducted the most profound study of the characteristic phonetic and morphological features of the peripheral dialect that distinguishes it from the remaining dialects. The features include the following: lack of phonemic merger, lack of narrowed $/ \mathrm{a} /$, consonant pronunciation of the nasal vowels before fricatives, denazalization $/ \mathrm{a} /$ at the end of the word, propensity to prolong accentuated vowels and reduce unstressed vowels, and the absence of opposition to masculine and non-masculine personal forms. In addition, there is a significant amount of vocabulary in common with Ukrainian. The type of Polish language formed on the frontier had a reverse effect on the development of the common literary Polish language and acted as a mediator of Ukrainian's influences on Polish since this dialect occupied a significant territory of the Commonwealth. In addition, it was the language of prominent writers, religious and educational figures as well as wealthy families, who played a major role in the socio-political life of the country. According to S. Urbańczyk, the influence of the peripheral dialect lasted from the 17th to the 19th century since the political and cultural role of the nobles in the borderlands during this time did not decrease (1979, p. 276). These strata of the frontier population caused changes in the Polish literary language since they were able to distribute linguistic innovations giving them the status of general or even normative, for example, in printed texts. Furthermore, there was evident influence of the Ukrainian language, which includes the following: the tendency toward diminutive forms (okieneczko, wianeczek, cichuczeńko, stowiczek, gardleczko, ostrożniuchno), the replacement of the vocative by the nominative, and the absence of the encyclical forms of pronouns. In addition, there was the constant placement of się after the verb and not after the word that is logically stressed in the sentence. Other influences include the constant use of personal pronouns with the verb in the past form while personal endings of this verb were omitted as well as the borrowing of Ukrainian lexical elements, such as hoży, hreczka, sioło, molodyca, nezabudka, chata, holoble, hultaj.

Writers, namely the ones from the borderlands, played the most important role in spreading Ukrainian borrowings. Ukrainian themes, plots and certain lexemes denoting Ukrainian reality are present in the works of S. Klonowic, S. Orzechowski, S. Pękala, M. Stryjkowski, J. Wereszczyński, M. Sęp Szarzyński, S. Grochowski, A. Chahrovskyi, J. Szczęsny Herburt, and others. They quickly spread in Polish fiction. Initially, the Polish interest in Ukrainian culture manifested in the descriptions of the region. For instance, S. Klonowic's Roxolania discusses Chervona Rus to a great extent as well as the traditions of Ukrainian villages, which means the text had to use Ukrainian words, such as bies, chata, czoboty, czupryna, czuryto, dubas, gramota, holoble, hultaj, kozera, mołojec, pop (Hrabec, 1949, p. 68 - 70). There is a significant number of religious terms in Ukrainian, such as praznik, pop, blahy, wierny, sud, in a pamphlet called "Baptismus Ruthenorum". It was written by S. Orzechowski, who was a known representative of the Polish Renaissance and the author of the popular expression: "Ggente Ruthenus natione Polonus". In "Baptismus Ruthenorum", Orzechowski advocates for the legality and equality of Eastern faith (Hrabec, 1949, p. 49 - 51).

The specific manner of the use of the Ukrainian theme in Polish literature and culture was evident after the loss of Poland's independence and territorial integrity in the 17th century when a significant part of the Polish lands and Right-Bank Ukraine became part of Russia, which imposed its administrative and economic policy. Polish literature cultivated the idea of Ukrainian-Polish unity; there was a feeling of nostalgia for the glorious historical past when brave Cossack knighthood guarded the great and mighty Commonwealth. It can be argued that in the 19th century, Polish fiction became a bearer of Ukrainian culture. The Polish writers who came from ethnic Ukrainian lands or were closely connected with the frontier wrote works in Polish on Ukrainian subjects with the evident influence of the Ukrainian language. They were J. Kraszewski, T. Jeż, D. Bonkovskyi, S. Ostaszewski, T. Padurra, J. Słowacki, and others. In particular, J. Słowacki called Ukraine a mother and masterfully depicted the difficulties of the Ukrainian-Polish relations in his Beniowski and Sen srebrny Salomei. An advocate for the reconciliation of both nations, the poet Vernyhora is a prophet to some extent, who proves that Słowacki attributed great importance to Ukrainian national poetry. Ukrainian elements are often used, especially in the works of the representatives of the so-called 
"Ukrainian school," among whom are V. Zaleski, S. Goszczyński, A. Malczewski, and M. Tchaikovsky. Due to their works, a number of Ukrainian borrowings became part of the literary Polish language, for example, ataman, bohater, borykać się, burzany, chata, dumka, hoży, hulać, jar, step, etc (Совтис, 2012, p. 178). Because of the formation of a Ukrainian-Polish ethnographic and cultural alliance on the borderlands, the inclusion of the religious atmosphere, history, and local traditions of the authors, they cannot be blamed for using mostly Polish for their works. In addition, the objective conditions of Polish, which was better developed as a literary language, possibly contributed to the choice of the language as well. Starting with the 16th century and continuing throughout the next three ones, certain Ukrainian writers took into account the achievements of Polish literature and wrote their works in Polish. Those writers include J. Wereszczyński, J. Szczęsny Herburt, M. Sęp Szarzyński, S. Szymonowic, J. and B. Zimorowic, P. Mohyla, M. Smotrytskyi, A. Radzyvylovskyi as well as the teachers at Kyiv-Mohyla college, L. Baranovych, J. Galatowski, I. Giesel, S. Kosiv, I. Oksenovych-Starushchyn, T. Prokopovych, D. Tupalo and S. Jaworski.

Regarding the writers with a double cultural identity, they felt free in both Ukrainian and Polish cultures and rooted for the prosperity of their "little" homeland. The Polish poet L. Venglinskyi, a representative of the "Ukrainian school," expressed his belief in the creative potential of the Ukrainian language: "To those who think that the Maloruska language as a lingua rustica (rural language) is not able to become a scientific and literary language on its own and without the help of Russian, we will answer that they are very much mistaken because the most beautiful language in the world, Italian, the 'language of angels' as Saphir called it, appeared in the suburbs of Rome" (Венглінський, 2011, p. 777). The poet gives interesting information about the attitude of the Poles to the Ukrainian language: "For a long time, Poles, who were lulled by Rusyn nannies with Maloruski songs, have loved this language, which is slightly different in the Carpathians, in Podillia and in Ukraine, and the songs of Rusyns always bring the feeling of nostalgia in their souls, especially when they are far from native land.... Among all Slavic languages, the Polish language is the most similar to the Rusyn dialect. Yet, it is not surprising! After all, the literary language of Kokhanovskyis, Orikhovskyis, Skarhas and Mickiewiczes was the result of the collaboration of Polish and Rusyn writers. This is the common property of both these peoples, which share history, customs and blood, good and bad times, so it is impossible to separate one from another after the generations of family ties.... Five centuries created this amalgam" (Венглінський, 2011, p. 778). It should be noted that unlike many Russian linguists who argued that the Ukrainian language existed only as a dialect of Russian, Polish linguists noted its separate status and ancient origin, which was confirmed by ancient written sources and by the existence of Ukrainian books and church language (Hrabec, 1949, p.1921). It is important to emphasize that the poet wrote his poetic Ukrainian texts using the Latin alphabet since he was a great supporter of it; thus, he tried to popularize Ukrainian works and become closer to European culture. The author was deeply convinced that for the Rusyns not to accept the Latin alphabet meant separation among the Slavs. In essence, his arguments were progressive. According to the author the aspiration for progress is what explains the publication in the Latin graphics of the works of Z. Pauli, W. Zaleski, T. Padura, P. Kostetskyi, Y. Fedkovych, among others as well as brochures, newspapers, and periodicals published in the "Maloruska language". T. Padura, a talented poet, a lyre player, a wandering turban player, who made a significant contribution to Polish and Ukrainian culture and music, also used the Latin alphabet in his works. Gaining inspiration from folklore and historical Cossack dumas of the Podillia, Volyn, and Kyiv region, he felt as if he was expressing Ukrainian people and being one of them. It is important to note that this type of thinking, which was called Gente Ruthenus natione Polonus, was a mass phenomenon among the nobles of the border areas. It was based on the combination of "local" patriotism, the cultivation of the people's language and customs as well as political patriotism and devotion to the state. In this case, the state was the Commonwealth of Poland, which included his own "small" homeland: Volyn, Podillia, the lands along the Dniester, among others. On the whole, the literary heritage of many writers of the Ukrainian-Polish border can be attributed to the common achievement of both countries, Ukraine and Poland. These artists with dual language and cultural identity, for whom the "private" homeland had a special value, played a significant role in popularizing and preserving the Ukrainian language and culture: "But you, Ukraine, you are my mother! Poland, my sweetest homeland!" (Padura, 2012, p. $356)$. 
There is a close Ukrainian-Polish collaboration in terms of culture. The "Cossack" theme became especially popular in the works of the Polish artists who created history and war paintings (Y. Mateiko, V. Pavlishak, Y. Brandt, and Y. Kossak). The use of Ukrainian motifs in fine arts did not have negative or political connotations. Cossacks were perceived as an integral part of Polish national history; therefore, the positive or negative evaluation of the images was determined only from the point of view of the Cossacks' influence on the historical processes in the state as a single, holistic organism.

Ukrainian songs or their arrangements were printed in almost every Polish literary magazine or almanac (Бажан, 1971, p. 7). Folk poetry inspired many art masterpieces. A number of musicians of Polish origin used Ukrainian folk songs. Among them were A. Kocipiński, M. Zawadzki, V. Zaremba, T. Hanetskyi, and others; they helped to preserve the basic traditions and combined them with instrumental music. A. Kocipiński, who worked in Podillia for a long time, had an interesting point of view. Due to his understanding of Ukrainian songs, the composer came to the conclusion about the unity of the Ukrainian nation: "The diversity (of Rusyn people from different regions) is not that great that a Rusin from the banks of the Dnipro would renounce the language and songs of his compatriots from the banks of the Dniester" (Kocipiński, 1862, p. 4). The composer names the Ukrainian people "Rusyns" and Ukrainian literature, "Ruska".

Another area of interest of Polish researchers was Ukrainian folklore, the study of which began in the 16th century and only deepened in the following centuries. In 1800, the "Warsaw Society of Friends of Sciences" was founded in Poland. One of its main tasks was the study of Ukrainian folk culture. The contributions of the prominent Polish folklorists, which include Z. Dołęga-Chodakowski, A. Fischer, V. Zaleskyi, Z. Pauli, S. Izopolskyi, K. Simenskyi, and O. Kolberh, are invaluable to the studies of the western regions of Ukraine and preservation of ethnic traditions and remain an authoritative resource not only for philologists but also for folklorists, anthropologists, and ethnologists.

Thus, in the context of Ukrainian-Polish contacts at the frontier, a unique situation was created when a higher imperial culture borrowed from a subordinate culture, a rural, folk tradition, which became ideologically and thematically dominant in Polish literature, painting, and music.

In conclusion, despite the continued coexistence within a single state and dominant Polish linguistic and cultural influence, Ukrainian culture, folk traditions, and, most importantly, the Ukrainian language as the main attribute of the nation's existence were preserved on the western Ukrainian borderland. Moreover, due to the peripheral Polish dialect and the popularization of the Ukrainian language in Polish fiction, Ukrainian elements were integrated into the Polish language. Polish artists, whose life and creative paths were associated with Kresy, played an important role in popularizing Ukrainian elements. The writers who came from Ukrainian lands, for whom the traditions of the Ukrainian people were native, created national literature based on local language and folklore. The texts that appeared at the intersection of two cultures could be called multicultural, and they require special approaches in contemporary research.

Nowadays, the common history is reconsidered and the Cossack past and the Polish nostalgia for the "little" homeland are gradually becoming a thing of the past. The memories of a certain territory belonging to a common Polish territorial organism remain, which poses new questions.

Thus, Ukrainian-Polish relations remain a rich source of study for diverse interdisciplinary research. The frontier deserves particular attention since it is where significant linguistic and cultural interactions have occurred and are happening and where local people, whether Ukrainian or Polish, continue to use both languages without any problems. At the present stage, the scope and content of such a concept as "the dialogue of languages and cultures" is undergoing a certain revision. Literary studies are acquiring new features and angles; the range of issues and problems is expanding and becoming more complicated. On the whole, the perspective of this research is in the further analysis of the bilingual art of the Ukrainian-Polish frontier authors.

\section{REFERENCES:}

Бажан, М. (1971)
Українською музою натхненні (Польські поети, які писали українською мовою). Київ: Радянський письменник, 303 с. (Bazhan, M., ed. Ukrajins'koju muzoju natxnenni (Pol's'ki poety, jaki pysaly ukrajins'koju movoju). Kyiv: Radianskyi pysmennyk, 303 s.) 
Венглінський, Л. (2011)

Грушевський, М. (1991)

Кирчів, Р. (2009)

Падура, Т. (2012)

Совтис, Н. (2012)

Сухомлинов, 0 . (2008)

Hrabec, S. (1949)

Kocipiński, A. (1862)

Kurzowa, Z. (1993)

Kurzowa, Z. (1983)

Nitsch, K. (1954)

Rieger, J. (1993)

Suchomłynow, L. (2007/2008)

Uliasz, S. (1994)

Urbańczyk, S. (1979)
Вибрані поезії українською мовою. Київ: Університет Україна, 800 с. (Venhlinskyi, L. Vybrani poeziji ukrajins'koju movoju. Kyiv: Universytet Ukraina, $800 \mathrm{~s}$.)

Хто такі українці і чого вони хочуть. Київ: Товариство Знання України, 240 c. (Hrushevskyi, M. Xto taki ukrajinci i čoho vony xočut'. Kyiv: Tovarystvo Znannia Ukrainy, $240 \mathrm{~s}$.)

Етнокультурне пограниччя: контури предметного поля і методологічні засади його дослідження. - В: Народознавчі зошити, № 5 - 6, с. 594 - 607 (Kyrchiv, R. Etnokul'turne pohranyččja: kontury predmetnoho polja i metodolohični zasady joho doslidžennja. - V: Narodoznavchi Zoshyty, 5 - 6, s. 594 - 607.)

Вибрані твори. Київ, 623 с. (Padura, T. Vybrani tvory. Kyiv, 623 s.)

Українські лексичні запозичення в польській літературній мові. Рівне: О. Зень, 200 с. (Sovtys, N. Ukrajins'ki leksyčni zapozyčennja v pol's'kij literaturnij movi. Rivne: O. Zen, 200 s.)

Культурні пограниччя: Новий погляд на стару проблему. Донецьк: ТОВ Юго-Восток, 212 с. (Sukhomlynov, O. Kul'turni pohranyččja: Novyj pohljad na staru problemu. Donetsk: TOV Iuho-Vostok, $212 \mathrm{~s}$.)

Elementy kresowe w języku niektórych pisarzy polskich XVI i XVIII w. Toruń: Towarzystwo Naukowe, $159 \mathrm{~s}$.

Piśni, Dumki i Szumki Ruśkoho Naroda na Podoli, Ukraini i w Małorossyji. Kyiv, 306 s.

O Mowie Polaków na Kresach Wschodnich. Kraków: Nauka dla wszystkich, 62 s. Polszczyzna Lwowa i Kresów Południowo-wschodnich do 1939 roku Warszawa, Kraków: PWN, 474 s.)

O wzajemnym stosunku gwar ludowych i języka literackiego. - W: Wybór pism polonistycznych, t. 1, Wrocław, s. $193-218$.

Język polski na Wschodzie. - W: Encyklopedia kultury polskiej XX wieku, t. 2. Współczesny język polski. - Wrocław, s. 547 - 560.

Specyfika polsko-ukraińskiego dyskursu pogranicza // Rocznik Wschodni, n. 13, s. $183-191$.

Literatura Kresów - Kresy Literatury: Fenomen Kresów Wschodnich w Literaturze Polskiej Dwudziestolecia Międzywojennego. Rzeszów: Wyższa szkoła pedagogiczna, $244 \mathrm{~s}$.

Przyczyny zaniku samogłosek pochylonych w języku polskim. - W: Prace $\mathrm{z}$ dziejów języka polskiego, Warszawa: Zakład Narodowy im. Ossolińskich. S. 265 -277 . 